\title{
KEPRIBADIAN GURU KRISTEN DALAM PERSPEKTIF 1 TIMOTIUS 4:11-16
}

\author{
Talizaro Tafona'o \\ Sekolah Tinggi Teologi Kadesi Yogyakarta \\ Weron, Balong RT/RW 002/012, Umbulharjo, Cangkringan, Sleman-Yogyakarta \\ Email: talizarotafonao@gmail.com
}

\begin{abstract}
Talizaro Tafonao, Christian Teacher Personality in Perspective of 1 Timothy 4: 11-16. One important indicator that must be known by Christian teachers is to have a good personality. Trough this research, author describes the Christian Teacher Personality in Perspective of 1 Timothy 4: 11-16. Authors used qualitative research methods in doing study of the text 1 Timothy 4: 11-16 to analyze the Bible's point of view of the personality of Christian teachers. The results of these research analysis are: First, Being in words. Based on this text, Timothy was instructed to be an ensamples in words, both of personal conversations with several people and those delivered in public. Second, ensamples in Love. This love refers to love between humans and between human and God. God desired all human to love one another, with agape love, because the other third love, named storge, philo and eros will properly function if it is based on agape love. Third, ensamples in holiness. Holy and pure life needs to be developed and struggled for because God has delivered and saved. Holiness means clean, free from sin, sacred etc Thus, the successful of a Christian Religion teacher is having a personality.
\end{abstract}

Key Words: Personality, Christian Teacher, Timothy.

\begin{abstract}
Abstrak: Talizaro Tafonao, Kepribadian Guru Kristen Dalam Perspektif 1 Timotius 4:11-16. Salah satu indikator penting yang harus diketahui oleh guru Kristen adalah memiliki kepribadian yang baik. Dari karya tulis ini, penulis mendreskripsikan Kepribadian Guru Kristen Dalam Perspektif 1 Timotius 4:11-16. Dalam menemukan jawaban penelitian ini maka penulis menggunakan metode penelitian kualitatif dengan melakukan kajian terhadap teks 1 Timotius 4:11-16 untuk menganalisis pandangan Alkitab tentang kepribadian guru Kristen. Setelah penulis melakukan kajian terhadap teks tersebut di atas, maka adapun hasil analisisnya adalah: Pertama, Keteladanan dalam perkataan. Dalam hubungannya dengan konteks ini, Timotius diperintahkan untuk menjadi teladan dalam perkataan, baik yang ia sampaikan secara pribadi kepada beberapa orang maupun yang disampaikan di depan umum. Kedua, Keteladan Dalam Kasih. Kasih ini dinyatakan pada sesama manusia dan kepada Tuhan. Allah menghendaki agar manusia saling mengasihi satu dengan yang lain, dengan kasih agape, sebab ketiga kasih, yakni storge, philo dan eros hanya dapat berfungsi dan terjalin dengan baik sebagaimana mestinya jika didasari oleh kasih agape. Ketiga, Teladan Dalam Kesucian. Hidup suci dan murni perlu dikembangkan dan diperjuangkan karena Tuhan yang telah membebaskan dan menyelamatkan.Jadi kesucian adalah bersih, bebas dari dosa, keramat dan lain-lain.Dengan demikian, keberhasilan seorang guru Agama Kristen harus memiliki kepribadian.
\end{abstract}

Kata Kunci: Kepribadian, Guru Kristen, Timotius.

\section{PENDAHULUAN}

Kajian Kepribadian Guru Kristen dalam Perspektif 1 Timotius 4:11-16 adalah salah satu indikator penting yang harus diketahui oleh guru Kristen. Sebab menjadi guru adalah sebuah panggilan jiwa. Tung (2016, p. 2) menjelaskan bahwa "menjadi pendidik Kristen bukanlah pilihan, melainkan panggilan untuk bersaksi". Oleh sebab itu, pada saat rekrutmen calon-calon guru termasuk guru agama Kristen Se- kolah Dasar tidak cukup hanya mengukur kualitas semata yaitu terkait dengan penguasaan bahan ajar, penguasaan teori dan ketrampilan keguruan, serta memiliki kemampuan memperagakan unjuk kerja sebagai calon guru. Mutu guru agama Kristen sebagai hamba Tuhan juga perlu ditilik dari hidup kerohanian atau spiritualitasnya (Sidjabat, 1999, p. 137). Maksudnya guru agama Kristen, selalu dituntut darinya sesuatu yang berkaitan dengan kepribadiannya 
yang diwujudkan dalam cara hidup, dengan pertanggung jawaban keagamaan dan moral. Kualitas hidup serta kinerjanya diharapkan berbeda dari guru lain, karena pekerjaannya harus dipertanggungjawabkan kepada Tuhan, Sang Guru Agung pemberi pekerjaan itu. Menurut hemat Tung (2016, pp. 5) bahwa pendidikan Kristen adalah memuridkan, menggerakkan anak-anak dekat dengan Tuhan. Mendidik anak dalam Kristus adalah mendidik dalam kepemimpinan yang spiritual, sebab guru agama Kristen adalah seorang yang di dalam dirinya sendiri memiliki keyakinan, kepercayaan yang teguh, ibadah yang baik, memiliki sifat moral yang baik dan hidup dalam kesucian, memiliki kebajikan yang sesuai dengan agamanya sehingga ia mengerjakan segala sesuatu dengan bertanggung jawab untuk kekekalan (Tong, 2008, p. 9). Setiap orang Kristen adalah hamba Tuhan, dan setiap hamba Tuhan menerima panggilan dari Tuhan untuk melaksanakan perannya sesuai panggilannya tersebut. Panggilan itu berbeda-beda, tetapi tiap panggilan itu mempunyai keluhuran dan kegunaannya masing-masing. Guru agama Kristen adalah hamba Tuhan, dipanggil untuk melaksanakan kehendak-Nya, melalui tugas keguruan yang dipikul atau diembannya (Sidjabat, 1999, p. 163). Berhubungan dengan kompetensi pribadi, Kunandar (2007, p. 55) menyatakan, "Kompetensi pribadi adalah seperangkat perilaku yang berkaitan dengan kemampuan individu dalam mewujudkan diri sebagai pribadi yang mandiri untuk melakukan transformasi diri, identitas diri, dan pemahaman diri."

Selanjutnya, Uan (2001, p. 26-27) menggambarkan bahwa "kompetensi kepribadian terkait dengan penampilan sosok guru sebagai individu yang mempunyai kedisiplinan, penampilan baik, bertanggung jawab, memiliki komitmen, dan menjadi teladan. Sedangkan kepribadian sangat berkaitan erat dengan pribadi guru sebagai individu yang memiliki kepribadian yang utuh dan dewasa. Gultom (2007, p. 39-40) memaparkan bahwa standar kompetensi kepribadian yang harus dimiliki para pengajar kristiani meliputi memiliki integritas yang mantap, memiliki kepribadian yang dewasa, berpikir alter- natif, mempunyai sifat jujur, adil, dan obyektif, berdisiplin dalam menjalankan tugas, memiliki kepribadian yang arif, berwibawa, dan memiliki akhlak dan dapat menjadi teladan. Guru Agama Kristen bukan hanya kematangan dalam pengetahuan tetapi juga keteguhan kepribadian, karena kepribadian menyangkut totalitas hidup manusia. Nainggolan (2006, p. 1) menyatakan

Bukan hanya sekedar transfer ilmu pengetahuan, tetapi lebih dari itu merupakan sarana untuk menanamkan iman kekristenan kepada anak didik. Menanamkan iman Kristen adalah ajakan Allah untuk bekerjasama: guru agama Kristen sebagai penabur benih iman dan Allah yang menumbuhkan.

Tung (2016, pp. 5) menambahkan bahwa

Guru Kristen adalah guru yang memiliki otoritas dalam kelas. Otoritasnya digunakan dalam penatalayan pekerjaan Tuhan. Guru Kristen memiliki otoritas dalam menjalakan mandate Injil, mengajarkan kebenaran dan keteladanan. Setiap guru Kristen harus bisa berkata "Temle of God is here". Guru Kristen adalah gembala bagi murid-muridnya. Guru menunjukkan jalan keselamatan dan hidup.

Namun perlu diketahui bahwa guru tidak hanya sebagai pengajar yang hanya memberikan ilmu, tetapi guru memiliki peran penting sebagai pendidik dan pembimbing untuk memperlengkapi siswa dalam semua tahap pertumbuhannya (Lebar, 2006, p. 76). Oleh karena itu dalam mengemban tugas yang mulia ini, guru Kristen dituntut mampu menjadi teladan dan menunjukkan kepribadian sebagai pendidik. Menurut Ciputra \& Tanan (2002, p. 120) mengatakan

Kepribadian adalah fakta sejati atau kondisi sesungguhnya dari seseorang.Ini merupakan kombinasi dari temperamen ditambah pengalaman masa kecil, pendidikan, pelatihan, pengalaman hidup, motivasi, keyakinan, atau sistem nilai. Kepribadian baru terlihat jelas setelah jangka waktu tertentu.

Pendapat lain menyatakan bahwa, "Istilah "kepribadian' berasal dari bahasa Yunani charassein, yang berarti membuat tajam atau membuat dalam" (Bagus, 1996, p. 392). Rutland (2009, p. 1) mengemukakan bahwa, kepribadian berasal dari akar kata bahasa Latin yang berarti 'dipahat'. Hal ini berarti bah- 
wa kepribadian adalah gabungan dari kebajikan dan nilai-nilai yang dipahat di dalam batu hidup, akan menyatakan nilai yang sebenarnya.

Secara harfiah kepribadian berarti, kualitas mental atau moral, kekuatan moral, nama atau reputasi, (Parnwell, et. al., 1972, p. 49). Kertajaya (2010, p. 3) menyatakan bahwa,

Kepribadian adalah 'ciri khas' yang dimiliki oleh suatu benda atau individu. Ciri khas tersebut adalah 'asli' dan mengakar pada kepribadian benda atau individu tersebut, dan merupakan 'mesin' yang mendorong bagaimana seseorang bertindak, bersikap, berujar, dan merespon sesuatu.

Dengan kata lain, kepribadian meliputi segala corak tingkah laku individu yang terhimpun dalam dirinya, yang digunakan untuk bereaksi dan menyesuaikan diri terhadap segala rangsang, baik yang datang dari luar atau lingkungan (eksternal) maupun dari dalam diri sendiri (internal) sehingga corak tingkah laku tersebut merupakan suatu kesatuan fungsional yang khas bagi individu (Sari, et. al., 2016, p. 3). Selanjutnya menurut penjelasan Nahampun (2017, p. 5410) mengatakan guru yang memiliki kepribadian yang baik dan stabil akan ditujukkan lewat sikap dan tindakannya yang sesuai dengan norma hukum, norma sosial. Hal ini berarti bahwa kepribadian mengacu kepada serangkaian sikap (attitudes), perilaku (behaviors), motivasi (motivations), dan keterampilan (skills). Orang yang berkepribadian baik atau unggul adalah orang yang berusaha melakukan hal-hal yang terbaik terhadap Tuhan, dirinya, sesama, lingkungan, bangsa dan negara pada umumnya dengan mengoptimalkan potensi dirinya dan disertai dengan kesadaran, emosi dan motivasinya. Itu sebabnya rasul Paulus berpesan dan menasihati Timotius,

Beritakanlah dan ajarkanlah semuanya itu. Jangan seorang pun menganggap engkau rendah karena engkau muda. Jadilah teladan bagi orangorang percaya, dalam perkataanmu, dalam tingkah lakumu, dalam kasihmu, dalam kesetiaanmu dan dalam kesucianmu. Sementara itu, sampai aku datang bertekunlah dalam membaca Kitab-kitab Suci, dalam membangun dan dalam mengajar. Jangan lalai dalam mempergunakan karunia yang ada padamu, yang telah diberikan kepadamu oleh nubuat dan dengan penumpangan tangan sidang penatua. Perhatikanlah semuanya itu, hiduplah di dalamnya supaya kemajuanmu nyata kepada semua orang. Awasilah dirimu sendiri dan awasilah ajaranmu. Bertekunlah dalam semuanya itu, karena dengan berbuat demikian engkau akan menyelamatkan dirimu dan semua orang yang mendengar engkau. (Tim. 4:11-16.)

Jika diperhatikan teks di atas (4:11-16), terlihat jelas bahwa terdapat dua kepribadian utama yang harus dimiliki seorang pengajar, yakni keteladanan (ayat 12) dan ketekunan (ayat 11,13-16). Kedua kepribadian ini menjadi conditio sine qua non yang harus melekat sebagai kepribadian diri seorang pengajar (guru Kristen).

Douglas (1995, p. 479) menjelaskan bahwa surat kepada Timotius dan Titus, disebut sebagai surat penggembalaan dan dialamatkan kepada dua orang rekan sekerjanya yang paling akrab, oleh karena itu ketiga surat Paulus itu berbeda dari surat-suratnya kepada jemaat-jemaat terdahulu. Sementara Kee (1991, p. 235) mendefinisikan surat pastoral dengan, "They contain Instructions and admonition for the fulfillment of the pastoral office in the Christian communities." Surat-surat penggembalaan tidak hanya ditujukan kepada para gembala sidang dan para pekerja Kristus yang melayani sepenuh waktu, tetapi juga ditujukan kepada setiap orang Kristen. Kummel yang dikutip oleh Kee (1991, p. 235) mengatakan bahwa, melalui surat-surat penggembalaan, Paulus sedang menyediakan bagi generasi penerusnya petunjuk penggembalaan. Dapat disimpulkan bahwa jika dikaitkan dengan pendidikan, maka surat pastoral berisi petunjuk-petunjuk mengenai bagaimana menjadi seorang pendidik yang benar dan bagaimana seharusnya mendidik.

Surat 1 Timotius 4:11-16 merupakan kelanjutan dari nasihat Paulus kepada Timotius untuk menjadi pengajar sekaligus sebagai pendidik warga jemaat di kota Efesus. Jemaat di Efesus yang dipimpin oleh Timotius sedang menghadapi pergumulan dan tantangan besar bagi pertumbahan imannya, dimana hadirnya pengajar-pengajar yang menyesatkan. Melalui nasihatnya Paulus memberi tugas kepada 
Timotius untuk memperkuat iman jemaat melalui pengajaran dan pendidikan yang benar, sehingga jemaat di Efesus terhindar dari penyesatan dan tetap setia kepada Tuhan Yesus.

Apa yang tertulis dalam 1 Timotius 4:1-10 itu harus diumumkan kepada orang Kristen. Mereka harus dididik dalam ajaran sehat dan menolak ajaran palsu. Injil harus menguasai masalah-masalah dalam kehidupan sehari-hari (Haak, 1999, p. 106). Dari nasihat Paulus ini, tampak harapan Paulus bahwa Timotius tidak hanya perlu belajar kebenaran Injil Kristus tetapi ia harus memberitakan dan mengajarkannya. Timotius harus menerapkan apa yang telah diperolehnya melalui tindakan, usaha, dan perjuangannya "memberitakan, mengajar" kebenaran yang diperolehnya kepada jemaat yang sedang mengalami tantangan penyesatan. Pada ayat ini pula dapat diketahui bahwa Timotius sebagai pemberita dan pengajar harus sungguh-sungguh bertekun mengajarkan kebenaran Injil Yesus Kristus. Sebagai seorang pengajar dan pendidik Timotius harus dapat mengatasi segala sesuatu yang berpotensi untuk menyulitkan, mencemarkan, menghalangi, bahkan menggagalkan pengajaran dan pendidikan yang dilakukannya. Untuk itu, kepribadian menjadi kata kunci yang harus Timotius cermati dan perhatikan. Ia tidak boleh membiarkan umurnya menjadi perintang bagi dirinya atau batu sandungan bagi orang lain. Karena itu, ia perlu menjadi teladan dalam perkataan, tingkah laku, kasih, dan kesuciannya (ay. 12). Timotius juga diminta untuk tetap bertekun dalam pembacaan dan pengajaran nas-nas Kitab Suci di antara jemaatnya (ay. 13), tidak lalai dalam mempergunakan karunia yang Tuhan berikan padanya (ay. 14), dan sungguh-sungguh membiarkan hidupnya dikuasai oleh hal-hal yang baik tersebut, sehingga kemajuannya nyata bagi orang-orang di sekitarnya (ay.15). Timotius juga harus mengawasi dirinya sendiri dan ajaran dan pendidikannya (ay. 16). Kesemuanya itu harus dilakukannya dalam ketekunan (ay. 16). Singkatnya, Timotius harus memperhatikan dan memiliki kepribadian rohani sebagai pengajar dan pendidik bagi orang di sekitarnya. Orang yang berkepribadian adalah orang yang memiliki berwatak yang baik. Bila dilihat dari asal katanya, "Istilah 'kepribadian' berasal dari bahasa Yunani karasso, yang berarti 'cetak biru' format dasar atau 'sidik' seperti dalam sidik jari." (Koesoema A., 2010, p. 90). Pendapat lain dikemukakan oleh Bagus (1996, p. 392) yang menyatakan bahwa, 'Istilah 'kepribadian' berasal dari bahasa Yunani charassein, yang berarti membuat tajam atau membuat dalam." Rutland (2009, p. 1) mengemukakan bahwa kata kepribadian berasal dari bahasa Latin yang akar katanya memiliki arti berarti 'dipahat'. Hal ini berarti bahwa kepribadian adalah gabungan dari kebajikan dan nilai-nilai yang dipahat di dalam batu hidup, akan menyatakan nilai yang sebenarnya.

Guru yang memiliki arti "digugu dan ditiru" secara langsung memberikan pendidikan kepribadian kepada peserta didiknya. Sebab itu, profil dan penampilan guru seharusnya memiliki sifat-sifat yang dapat membawa peserta didiknya ke arah pembentukan kepribadian yang kuat, karena guru adalah teladan peserta didik. Pendidikan tak cukup hanya untuk membuat anak pandai, tetapi juga harus mampu menciptakan nilai-nilai luhur kepribadian. Karena itu, penanaman nilai-nilai luhur harus dilakukan sejak dini. Kepribadian yang berkualitas perlu dibangun, dibentuk dan dibina sejak usia dini, karena usia dini merupakan masa kritis bagi pembentukan kepribadian seseorang. Tindakan, perilaku, dan sikap anak saat ini bukanlah sesuatu yang tiba-tiba muncul atau terbentuk tetapi ada proses panjang sebelumnya yang membuat sikap dan perilaku tersebut melekat pada diri anak. Oleh karena itu, keluarga, sekolah, dan lingkungan tidak bisa lepas dalam membentuk kepribadian anak-anak. Ketiga pihak tersebut harus ada hubungan yang sinergis.

Dari latar belakang di atas, rumusan masalah artikel ini adalah bagaimana pandangan Alkitab, khususnya 1 Timotius 4:11-16 tentang kepribadian guru Kristen. Dari rumusan tersebut, penulis melakukan analisis dengan tujuan untuk memaparkan pandangan Alkitab, khususnya 1 Timotius 4:11-16 tentang kepribadian guru Kristen. Kajian ini diharapkan 
dapat memberikan wawasan bagi pengembangan teologi praktika khususnya pendidikan Kristen.

\section{METODE}

Metode penelitian yang digunakan dalam penulisan artikel ini adalah metode penelitian kualitatif. Menurut Sugiyono (2014, p. 347), mengatakan bahwa metode penelitian kualitatif adalah dapat diartikan sebagai metode penelitian yang digunakan untuk meneliti kondisi objek yang almiah, dimana peneliti berperan sebagai instrument kunci, teknik pengumpulan data dilakukan secara trianggulasi (gabungan). Sumber data yang dipakai dalam penelitian kualitatif berupa lingkungan alamiah.

Kajian utama dalam penelitian eksegesis adalah peristiwa-peristiwa yang terjadi dalam kondisi dan situasi sosial. Penulis melakukan analisis data dengan memperbanyak informasi, mencari hubungan ke berbagai sumber, membandingkan, dan menemukan hasil atas dasar data sebenarnya (tidak dalam bentuk angka). Dalam tulisan ini, penulis mengkaji teks 1 Timotius 4:11-16 untuk menganalisis pandangan Alkitab tentang kepribadian guru Kristen. Sumber utama dalam penulisan ini adalah Alkitab. Proses analisis yang dilakukan oleh penulis adalah menggunakan berbagai sumber pustaka maupun elektronik yang terpercaya untuk mendukung analisis penulis. Untuk menghindari kesalahan dalam proses intepretasi teks Alkitab, penulis meminta kepada sejawat untuk memeriksa hasil analisis yang penulis lakukan.

\section{HASIL DAN PEMBAHASAN}

Hasil analisis terhadap teks 1 Timotius 4:1116, penulis menemukan beberapa kepribadian guru Kristen.

\section{Keteladanan}

Kualifikasi kepribadian seorang pengajar yang harus dimiliki oleh Timotius adalah "Keteladanan." Kepada Timotius, Paulus berkata "Jangan seorangpun menganggap engkau rendah karena engkau muda. Jadilah teladan bagi orang-orang percaya, dalam perkataanmu, dalam tingkah lakumu, dalam kasihmu, dalam kesetiaanmu dan dalam kesucianmu (ay. 12). Dalam teks berbahasa Yunani versi BGT, tertulis: "Mhdej sou th' neothtoj kataf roneitw alla. tupoj ginou twh pistwh ea logw ea

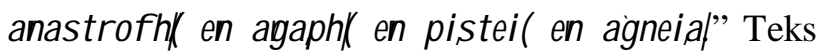
tersebut diterjemahkan dalam versi BIS sebagai berikut:

Janganlah membiarkan seorang pun menganggap engkau rendah karena engkau masih muda. Sebaliknya, hendaklah engkau menjadi teladan bagi orang-orang percaya dalam percakapanmu dan kelakuanmu, dalam cara engkau mengasihi sesama dan percaya kepada Yesus Kristus, dan dengan hidupmu yang murni.

Dalam ayat ini, kata Mhdej secara harafiah berarti "tidak ada seorang pun". Terjemahan bahasa Inggris menggunakan kata no one, tetapi beberapa terjemahan bahasa Inggris lainnya menambahkan kata don't atau let, misalnya NIV menggunakan don't let anyone atau YLT menggunakan frase let no one. Penerjemahan yang sama digunakan oleh Alkitab TB yang memakai frase "Jangan seorangpun". Beberapa pengertian kata Mhdaj sebagai berikut: 1) adj. no ( Kis.13:28; 25:17; 28:18; 1 Kor. 1:7; 1Ti 5:14; Ibr. 10:2); with another negative no...at all (2Kor. 6:3; 13:7; 1Pet. 3:6). 2) substantiv enhde, jnobody (Mat. 8:4; Mrk. 7:36; Ac. 9:7; 11:19; Ro. 12:17; 1Kor. 10:24; Why. 3:11). nhde,nothing (Mrk. 1:44; Lk 9:3; Kis. 8:24; Rm. 13:8; 1Kor. 10:25; Gal. 6:3); not at all, in no way (Mrk. 5:26; Luk. 4:35; Kis.4:21; Fil.4:6; Yak. 1:6). (Bahan elektronik, Bible Work 7).

Kata jangan, mengandung arti teguran kepada Timotius agar berdiri sebagai seorang pemimpin muda yang berani, tegas, kuat, dan tidak perlu merasa malu, demi keselamatan jemaat dari pengaruh ajaran sesat. Sebab itu, Rasul Paulus memerintahkan agar Timotius menjadi teladan. Kata ginou (ginu) adalah kata kerja imperatif untuk orang kedua tunggal yang diterjemahkan "jadilah". Kata ini didahului oleh kata tupoj (tupos) artinya teladan, tanda, contoh (Drewes, Haubeck dan von Siebenthal, 2006, p. 219). Sebenarnya kata tupoj (tupous) berarti pukulan. Beberapa penggunaannya, misalnya topon (tupon) 
yang diterjemahkan dalam ITB dengan tanda bekas (Yoh. 20:25); sesuatu bentuk yang terjadi karena pukulan; seperti tupouj (tupos) yang diterjemahkan dengan patung-patung (Kis. 7:43); tupon (tupon) diartikan juga sebuah desain ukuran yang dijadikan sebagai pola atau model (Kis. 7:44; Ibr. 8:5). Beberapa penggunaan lain adalah dalam hal bentuk tulisan (Rm. 6:17); dan menjadi contoh, pola, model dalam hal sikap (1Tim. 4:12). Secara khusus dalam 1 Tim. 4:12 menunjuk kepada sebuah contoh yang akan diikuti, yang dalam hal ini Timotius akan dijadikan contoh atau panutan. Artinya, Timotius dijadikan seorang yang meninggalkan sesuatu yang berkesan pada orang lain, hal mana membuat orang tersebut mengikutinya. Dari penjelasan di atas, dapat dipahami bahwa sebagai seorang pengajar, Timotius diminta oleh Paulus agar menjadi teladan bagi jemaat sekalipun dia masih muda. Permintaan ini mengandung makna bahwa pelayanan jemaat yang harus dilakukan Timotius adalah pelayanan keteladanan (1 Ptr. 5:3).

Keteladanan merupakan hasil dari tindakan proses ketaatan dan ketekunan akan firman Tuhan. Orang dikatakan teladan bila ia sudah melakukan hal yang benar dan berdampak positif bagi orang lain. Sebab itu, keteladanan merupakan sikap yang sangat dituntut oleh murid terlebih Tuhan.Keteladanan harus bersifat permanen dan saling berkaitan dengan kedewasaan rohani. Orang dewasa rohani adalah orang yang mempunyai integritas dan selalu berusaha untuk berbuah rohani.

Timotius telah dipanggil menjadi pelayan dan Paulus menasihati agar jangan merasa malu untuk mengajar, mendidik, dan memberitakan Injil, biarpun muda ketika ia menerima surat ini. Petunjuk untuk hal ini ditulis oleh Budiman (2008, p. 41),

Ketika ia dibawa kepada pertobatan oleh Paulus pada perjalanannya yang pertama (1Tim 1:2) pada tahun 44, Timotius berusia paling tinggi 15 tahun (2Tim 1:5; 3:15 yang menyinggung masa kecil Timotius). Ia kemudian diikutsertakan sebagai pembantu Paulus pada perjalanan ke-II (Kis. 16:1-3) pada saat itu Timotius berusia paling tinggi 33 tahun. Usia ini bagi seorang agama dan pembina jemaat pada zaman itu dianggap muda, karena ia berhadapan dengan orang-orang yang kebanyakan lebih tua dari padanya. Yang jelas para penatua yang harus ia beri instruksi-instruksi jauh lebih tua. Dan bagi mereka pasti tidak mudah untuk menerima instruksi-instruksi dari padanya

Barclay (2009, p. 153) menyatakan bahwa salah satu kesulitan Timotius adalah karena ia masih muda, tetapi bukan berarti ia masih remaja, sebab ia sudah menjadi pembantu Paulus selama 15 tahun. Kata Yunani yang digunakan untuk 'muda' adalah neotes, yang digambarkan sebagai usia untuk masuk militer hingga umur 40 tahun. Kanon rasuli menyatakan bahwa seseorang tidak boleh menjadi penilik jemaat sebelum umurnya lebih dari 50 tahun karena dengan itu 'ia telah melewati kenakalan masa muda'. Jika dibandingkan dengan Paulus, umur Timotius jauh lebih muda sehingga banyak orang akan memandangnya dengan sebelah mata. Sebab itu, Paulus mendorong agar Timotius menjadi teladan dalam hidup dan pelayanannya. Pelayanan yang dilakukan tidak hanya dengan kata-kata saja, tetapi yang terpenting yaitu harus disertai dengan sikap dan tindakan yang dapat menjadi panutan bagi seluruh jemaat. Dengan menjadi teladan, ia akan dihormati oleh orang-orang percaya twh pistwh (tōn pistōn). Henry (Matthew Henry's Commentary on the Whole Bible dalam eSword) menulis,

To confirm his doctrine by a good example: Be thou an example of the believers, etc. Observe, Those who teach by their doctrine must teach by their live, else they pull down with one hand what they build up with the other: they must be examples both in word and conversation. Their discourse must be edifying, and this will be a good example: their conversation must be strict, and this will be a good example: they must be examples in charity, or love to God and all good men, examples in spirit, that is, in spiritual-mindedness, in spiritual worship, - in faith, that is, in the profession of Christian faith, andin purity or chastity.

Bagi orang-orang percaya dari kata pistwh (piston) dalam bentuk adjective normal genitive masculine plural no degree dari kata pistoj (pistos). Artinya: 1) trustworthy, faithful, dependable, inspiring trust 
or faith (Mat. 25:21, 23; Luk. 16:10-12; 1 Kor. 1:9; 7:25; Kol. 4:7; 1Tit. 1:12, 15; 2Tim. 2:2, 13; Tit. 3:8; Ibr. 2:17; 10:23; Why. 2:13). 2) trusting, cherishing faith or trust, also believing, faithful (J 20:27; Ac 16:15; Gal 3:9; Eph 1:1). Of Christian believers (Ac 10:45; 16:1; 1Ti 4:3, 12; 6:2). (Bahan Elektronik, Bible Work 7). Timotius harus menjadi teladan dari kehidupan Kristen. Ia dituntut untuk memberikan teladan tentang apa yang diajarkan, yang diwujudkan di dalam kehidupan sehari-hari, sehingga orang tidak akan memandang dia rendah. Kata "menganggap rendah" dari kata Yunani kata fronetw (kataphroneito) dalam bentuk, orang ketiga tunggal, dari kata kata fronew (kataphroneo), artinya": 1) look down on, despise, scorn w. gen (Mat. 6:24; 18:10; Luk. 16:13; 1 Kor. 11:22; 1 Tim. 4:12; 2 Pet. 2:10; Tit. 2:15). Entertain wrong ideas about (Rm. 2:4; 1Tim. 6:2). 2) care nothing for, disregard, be unafraid of (Ibr. 12:2). (Bahan Elektronik, Bible Work 7). Budiman (2008, p. 41), menjelaskan,

Paulus ingin menabahkan hati Timotius dengan mengatakan bahwa orang tidak akan menganggap remeh dia, bila ia menjadi teladan bagi orang-orang percaya. Kewibawaan seorang pemimpin rohani tidak terutama terletak di dalam hal-hal lahiriah seperti usia, kekayaan, kepintaran, penggunaan kekerasan, melainkan di dalam keteladanan hidup. Bilamana orang percaya melihat di dalam pemimpinnya pencerminan Yesus Kristus, maka dengan sendirinya mereka akan menghormatinya, sama seperti mayang gandum tunduk kepada angin yang bertiup dan berlalu di ladang.

Sebagai seorang pengajar Timotius dituntut untuk memberikan teladan tentang apa yang diajarkan, yang diwujudkan di dalam kehidupan sehari-hari. Dengan menjadi teladan, ia akan dihormati oleh orang-orang percaya twh pistwh (tōn pistōn). Keteladanan Timotius harus nampak dalam lima aspek, yaitu: Pertama, Keteladanan dalam perkataan; kedua, Keteladanan dalam kasih, dan ketiga, Keteladanan dalam kesucian.

\section{Keteladanan dalam Perkataan}

Kalimat "metheis sou tes neotetos kataphroneito, alla tupos ginou ton piston en logo, en anas- trophe, en agape, en pistei, en agneia). "terdiri dari dari kata en logw(en logoi) yaitu kata benda datif (digunakan sebagai obyek penderita) maskulin tunggal. Berasal dari kata dasar I ogoj (logos) yang digunakan sebagai istilah umum untuk perkataan, tetapi juga sering sebagai kata atau berita (Mat. 22:46); bisa juga dipakai sebagai firman atau berita (dari Tuhan, Yoh. 1:1); juga dipakai untuk menyatakan isi dari pemberitaan (Luk. 5:1). Menurut Clarke (Adam Clarke Commentary of the Bible, Bahan Elektronik e-Sword) bahwa, "In doctrine; teach nothing but the truth of God, because nothing but that will save souls. Sedang menurut Barnes (Albert Barnes' Notes on the Bible, Bahan Elektronik e-Sword), "In "speech," that is, your manner of conversation. This does not refer to his "public teaching" - in which he could not probably be an "example" to them - but to his usual and familiar conversation."

Dalam hubungannya dengan konteks ayat ini, Timotius diperintahkan untuk menjadi teladan dalam perkataan, baik yang ia sampaikan secara pribadi kepada beberapa orang maupun yang disampaikan di depan umum. Perkataan ini di sini berhubungan erat dengan pengajaran tentang doktrin. Karena kata en I ogw|(en logoi) dalam bentuk tunggal maka yang dimaksudkan adalah seluruh perkataan Timotius harus menjadi panutan atau teladan bagi orang lain.

Perkataan selalu berhubungan dengan lidah. Lidah adalah bagian tubuh yang sekalipun kecil tetapi sulit untuk dikendalikan dan dikuasai. Firman Tuhan mengatakan bahwa jika seseorang bisa mengendalikan lidahnya maka ia adalah orang yang sempurna dan dapat juga mengendalikan tubuhnya. Yesus mengatakan, masalah lidah juga menyangkut masalah hati, karena 'yang diucapkan mulut meluap dari hati'. Orang yang dapat mengendalikan lidahnya adalah orang-orang yang mempunyai perbendaharaan yang baik dalam hatinya. Menurut Plato sebagaimana yang dikutip Unarto (2006, p. 128) bahwa orang bijak hanya berbicara jika mereka mempunyai sesuatu yang harus dikatakan; tetapi orang bodoh berbicara karena mereka harus mengatakan 
sesuatu. Sebab itu, setiap orang perlu mengendalikan apa yang mereka hendak katakan dengan menguasai lidahnya, karena adalah lebih baik untuk lambat berkata-kata daripada cepat berkata-kata dan selalu menemui masalah pada akhirnya. Dalam Yakobus 3:2 dikatakan, "Sebab kita semua bersalah dalam banyak hal; barangsiapa tidak bersalah dalam perkataannya, ia adalah sempurna, yang dapat juga mengendalikan seluruh tubuhnya." Itu berarti, menguasai lidah adalah hal yang sangat penting karena berhubungan dengan perkataan. Keteladanan dalam perkataan berarti penguasaan diri atas lidah dan ucapan yang dikeluarkan (Unarto, 2006, pp. 129-131). Tujuh hal pokok berkaitan dengan hal itu yakni: Pertama, keteladanan menyimpan rahasia. Setiap orang harus berusaha untuk dapat menyimpan rahasia orang yang telah dipercayakan kepadanya. Jika orang tidak mampu menyimpan rahasia maka ia akan dijauhi oleh teman-temannya. Seperti dikatakan, "Siapa mengumpat, membuka rahasia, sebab itu janganlah engkau bergaul dengan orang yang bocor mulut (Ams. 20: 19). Kedua, keteladanan dalam penguasaan lidah terhadap perkataan negatif. Perkataan yang negatif dapat memengaruhi orang-orang di sekelilingnya. Perkataan yang negatif dari sepuluh orang mata-mata yang diutus untuk mengintai tanah Kanaan mengecilkan hati semua orang Israel dan menyebabkan mereka berkeluh kesah dan mengeraskan hati terhadap janji-janji Allah. (Ul. 1:28). Ketiga, keteladanan untuk tidak mengucapkan kata-kata yang menyakitkan/cemooh. Mengolok-olok seseorang adalah perbuatan yang sangat menyakitkan hati, khususnya ketika seseorang mengolok-olok atau mempermainkan nama seseorang, mengejek keluarganya atau masalah fisiknya. Ketika seseorang melakukan sesuatu yang melukai hati, maka sebaiknya seseorang tidak perlu membalas dengan ucapan-ucapan yang juga menyakitkan. Tetapi sebaliknya harus belajar dari Tuhan Yesus yang setia mengendalikan bibir-Nya untuk tidak membalas, memaki-maki, mengancam dan menyumpahi orang yang telah menyakiti-Nya (Yes. 53:7; I Pet. 2:22-23). Keempat, keteladanan untuk tidak bicara tentang dusta dan tipu daya.Allah tidak suka dengan dusta atau tipu daya, sebab itu perintah untuk jangan mengucapkan saksi dusta termasuk di dalam kesepuluh firman (Kel. 20:16). Kelima, keteladanan untuk tidak memuji atau merayu berlebihan. Rayuan adalah salah satu bentuk dari perangkat Iblis. Manusia jatuh ke dalam dosa karena rayuan Iblis. Demikian pula, seseorang dapat jatuh karena kata-kata rayuan orang lain. Pujian yang tulus atau kata-kata yang membesarkan hati atau memberi semangat memang diperlukan dan sangat besar artinya, tetapi pujian yang berlebihan yang tidak sesuai dengan kenyataan merupakan suatu kebohongan yang berbahaya. (Maz. 5:10). Keenam, keteladanan dalam penguasaan lidah atas cerita-cerita dan humor jorok. Setiap orang harus menjauhi cerita-cerita dan humor yang jorok. Kata-kata yang kotor dapat membentuk gambaran yang kotor juga di dalam pikiran orang, baik yang mengatakan, maupun yang mendengarkan. (Kol. 3:8). Ketujuh, keteladanan untuk tidak terbawa arus untuk memfitnah atau menggosipkan. Kata-kata yang ditabur ke telinga orang lain akan bertumbuh. Jika yang ditabur adalah fitnah maka akibatnya akan timbul kepahitan dan buah-buah yang buruk. Istri Potifar memfitnah Yusuf yang mengakibatkan Potifar yang mendengarnya menjadi marah. (Kej. 39:17-19).

Perkataan memegang peranan yang sangat penting dalam kehidupan setiap orang khususnya dalam pergaulan dengan orang lain. Dalam sebuah keluarga, perkataan yang digunakan sangat berpengaruh pada perkembangan anak. Perkataan yang baik dapat memberikan kesehatan rohani, mental dan jasmani (Said, 2010, p. 92). Dalam Amsal dikatakan, "Perkataan yang diucapkan tepat pada waktunya bagaikan buah apel emas di pinggan perak (Ams. 25: 11). Allah mengajarkan agar setiap orang tidak menggunakan ucapan yang negatif, khususnya orang tua kepada anak-anaknya karena perkataan yang negatif seperti goblok, bodoh, canggung, malas, pemalu, buruk, dan lain-lain dapat membuat anak menjadi sosok yang tidak percaya. Segala ucapan negatif yang diterima anak akan melekat dalam hatinya, dan mereka akan cenderung menjadi sosok dan bertindak 
seperti julukan yang diberikan kepadanya. Daripada orang tua memberikan julukan negatif kepada anakanaknya, akan lebih baik jika orang tua atau guru memberikan pujian kepada anak-anaknya. Memuji anak-anak merupakan tindakan dan sikap yang positif (Nainggolan, 2008, p. 95-96). Dengan memberikan pujian kepada anak, mereka akan bertumbuh menjadi anak yang dapat bersyukur kepada Tuhan dan menghargai orang lain.

Dapat dipahami bahwa setiap orang, baik yang tua maupun yang mudah harus berusaha untuk dapat menguasai lidahnya sehingga setiap perkataan yang keluar dari mulutnya bukanlah perkataan yang sia-sia dan perkataan yang kotor, tetapi perkataan yang dapat membangun orang lain. Paulus mengatakan, "Janganlah ada perkataan kotor keluar dari mulutmu, tetapi pakailah perkataan yang baik untuk membangun, di mana perlu, supaya mereka yang mendengarnya beroleh kasih karunia" (Ef. 4:29). Abineno berkata istilah "sapros" (Yunani) berarti tua, rusak, rapuh, kotor. Karena itu dapat dijelaskan "logos sapros" dapat diterjemahkan sebagai perkataan yang buruk atau perkataan yang kotor yang akan mendatangkan kebinasaan. Kata-kata kotor yang membinasakan dikatakan keluar dari mulut sebetulnya berasal dari hati. Daripada menggunakan kata-kata kotor yang keluar dari hati, disarankan untuk menggunakan kata-kata yang bersifat baik dengan istilah yang digunakan Paulus "logos agathos." Sebab perkataan yang baik akan mendatangkan kebaikan atau membangun bagi yang mendengarnya. Membangun bagi mereka yang mendengarnya memiliki pengertian di mana para pendengar mendapatkan berkat dari Allah. (Abineno,1989, pp. 162-63). Itu berarti bahwa setiap orang dituntut untuk mampu menguasai lidahnya agar setiap perkataan yang diucapkan dapat membangun orang lain. Begitupun dengan Timotius, walaupun iamasih muda, tetapi ia harus menjadi teladan dalam perkataannya dengan tidak mengeluarkan kata-kata kotor, fitnah, gosip dan membicarakan keburukan orang lain. Dengan menjaga kesucian perkataan dan tingkah laku secara otomatis hal ini akan memberikan kesu- cian dalam hati dan pikiran. Karena ucapan dan perilaku merupakan cerminan hati dan pikiran. Hanya dengan kebersihan dan kesucian hati dan pikiran maka Timotius dapat menjadi teladan, bukan hanya bagi orang percaya saja, tetapi juga bagi semua orang yang mengenalnya. Timotius harus mewujudkan dalam kehidupannya apa yang diajarkannya dalam khotbahnya. Menurut Barnes (Albert Barnes's Notes) perkataaan atau khotbah yang tidak dapat dicela adalah khotbah yang murni dan sungguh-sungguh dalam bahasa, berbobot dalam penjelasan dan mempertahankan kebenaran doktrin. Henry (Matthew Henry's Commentary) juga menegaskan hal yang sama dengan memberikan penjelasan bahwa khotbah yang tidak dapat dicela adalah khotbah yang menggunakan bahasa yang mengekspresikan kebenaran Kitab Suci dengan tujuan untuk kehormatan Allah, Kristus dan kerajaan-Nya serta untuk kesejahteraan dan kebahagiaan manusia. Itu berarti, dalam melaksanakan pelayanan Timotius dituntut untuk mampu menjadi teladan dalam perkataan, yakni perkataannya harus baik, jelas, penuh hikmat, menguatkan dan dapat membangun orang lain. Apabila ada orang yang meminta petunjuk, maka perkataan atau jawaban Timotius harus benar sesuai dengan Alkitab atau firman Allah. Perkataan yang sehat adalah pesan dalam proporsi yang benar dan seimbang.

Berdasarkan uraian di atas peneliti menyimpulkan bahwa menjadi teladan dalam perkataan berarti seluruh perkataan, baik yang disampaikan secara pribadi kepada beberapa orang maupun yang disampaikan di depan umum khususnya dalam pengajaran, harus menjadi berkat bagi orang lain. Adapun langkah yang perlu ditempuh agar dapat menjadi teladan dalam perkataan adalah: menjaga hati, mengendalikan lidah untuk tidak mengucapkan perkataan kotor, berusaha menggunakan perkataan yang baik yang dapat membangun dan menjadi berkat bagi orang lain.

Jadi dapat disimpulkan bahwa keteladanan dalam perkataan berkaitan erat dengan Logos yang memiliki makna, yaitu: perkataan, pembicaraan, pemberitaan, firman dan pengajaran. Ini menyatakan 
bahwa seorang yang memiliki kepribadian sebagai pendidik dan pengajar harus selalu berkata-kata jujur dan penuh kasih. Menjadi teladan dalam perkataan berarti harus berkata jujur, mengucapkan kata-kata yang membangun, dapat memberi semangat atau dorongan kepada orang lain.

\section{Keteladan Dalam Kasih}

Dalam 1 Timotius 4:12 terdapat kata benda kasih yang diterjemahkan dari kata agaph (agapeii) datif maskulin orang pertama tunggal berasal dari kata agaph (agapē). Beberapa penggunaan kata agaph (agape) : kasih atau kehendak baik (Yoh. 15: 13; Rm. 13:10). Kasih ini dinyatakan pada sesama manusia dan kepada Tuhan. Kadang-kadang juga pemakaiannya untuk kasih Tuhan kepada manusia (Rm. 5:8; 8:39). Kasih adalah sifat Ilahi yang terutama dalam kehidupan Kristen. Kasih lebih besar dari iman dan pengharapan, lebih mulia dari segala karunia Roh Kudus yang ajaib, sebab kasih tidak berkesudahan. Semua akan lenyap, tetapi kasih tetap kekal selama-lamanya (1 Kor.13:8, 13). Tidak ada ciri seorang Kristen yang lebih menonjol daripada kasih (Graham, 1978, p. 308). Dengan demikian semua orang akan tahu, bahwa kamu adalah muridmurid-Ku, yaitu jika kamu saling mengasihi (Yoh. 13:35). Pasal yang paling agung mengenai kasih di dalam Alkitab adalah 1 Korintus 13. Karena jikalau kasih tidak menjadi ciri kehidupan seseorang, maka kosonglah kehidupannya (Graham, 1978, p. 309). Petrus berkata, "Tetapi yang terutama: kasihlah sungguh-sungguh seorang akan yang lain, sebab kasih menutupi banyak sekali dosa" (1 Pet. 4:8).

Dalam Bahasa Yunani terdapat tiga macam kasih yakni: Pertama, eros yaitu kasih birahi atau hawa nafsu manusia. Kedua, fileo yaitu kasih manusia secara alamiah, misalnya suami terhadap istri, ibu terhadap anak, dan sebagainya. Ketiga, agape yaitu kasih yang dinyatakan oleh Kristus (Senduk, tt, p. 41). Sementara Bahasa Yunani Sehari-Hari pada abad pertama menggunakan empat macam kasih yakni: Pertama, storge yaitu kasih sayang yang terjalin di antara anggota keluarga. Kedua, philos yaitu kasih yang terjalin dalam persahabatan. Ketiga, eros yaitu kasih yang bersifat romantis. Ketiga macam kasih ini merupakan pemberian Allah bagi manusia supaya manusia saling mengungkapkan kasihnya. Sedang yang keempat adalah agape yaitu kasih ilahi, kasih yang unik; kasih Allah kepada manusia (Roberts, 1988, p. 31). Barclay (2003, pp. 79-80) lebih rinci menjelaskan arti keempat istilah kasih tersebut. Pertama, agape yaitu kasih yang paling tinggi dan mulia, yang mana tidak melihat nilai dari objeknya. Ini digunakan untuk menjelaskan tindakan pengorbanan tanpa ada maksud yang jahat, baik bagi diri sendiri maupun bagi orang lain. Juga digunakan untuk menggambarkan kasih Allah kepada manusia, kasih manusia kepada Allah, dan kasih manusia kepada sesamanya dalam bentuk yang umum. Kedua, eros yaitu kasih yang dinyatakan kepada lawan jenis, pria dan wanita. Ketiga, philia yaitu kasih yang menunjukkan kehangatan yang diberikan kepada orang-orang yang dekat, seperti kawan. Keempat, storge yaitu kasih sayang yang lebih umum digunakan dalam hubungan keluarga, orang tua dengan anak-anaknya.

Konsep tentang agape banyak ditemukan dalam Kitab-kitab Perjanjian Baru. Pada waktu Yesus mengatakan, "Kasihilah musuhmu," dalam Injil Matius, Tuhan Yesus memakai kata agape. Pada waktu Yesus mengatakan, "agar para murid-Nya saling mengasihi," dalam Injil Yohanes, Yesus juga memakai kata agape. Pada waktu Yesus mengatakan, "Kasihilah sesamamu manusia," dalam Injil Markus, Ia memakai kata agape. Pernyataan bahwa "Allah adalah kasih," juga menggunakan agape. Dalam The New Bible Dictionary kata kasih agape didefinisikan dalam bahasa Yunani sebagai bentuk kasih yang tertinggi dan termulia, yang melihat obyeknya sebagai sesuatu yang sangat berharga (Graham, 1978, p. 310).

Allah menghendaki agar manusia saling mengasihi satu dengan yang lain, dengan kasih agape, sebab ketiga kasih, yakni storge, philo dan eros hanya dapat berfungsi dan terjalin dengan baik sebagaimana mestinya jika didasari oleh kasih agape. Ja- 
di, dengan adanya kasih agape, maka dalam suatu kehidupan yang suci, yaitu kehidupan yang dipimpin oleh Roh Kudus, ketiga macam kasih ini dapat berfungsi pada tempatnya dan terjalin dengan baik.

Ada perbedaan antara kasih yang merupakan kebutuhan dengan kasih yang merupakan pemberian/karunia (gift-love). Mengenai kasih yang merupakan kebutuhan Senduk (tt., 41) mengatakan bahwa kasih manusia berakar pada egoisme dan bergantung pada keadaan, misalnya jika ada kepentingan, keperluan, kesenangan, keuntungan, baru ada rasa kasih, sementara jika tidak ada kepentingan, maka tidak ada kasih. Manusia mengasihi Allah dan sesama karena adanya kebutuhan dalam dirinya, namun kasih Allah kepada manusia adalah kasih anugerah. Hanya Allah yang sanggup melimpahkan gift-love. Allah sendiri tidak membutuhkan apa-apa, tetapi adalah perintah Allah agar manusia mengalami dan memiliki agape. Ia menghendaki agar manusia mengasihi Allah dan sesama dengan kasih agape (Roberts, 1988, p. 32). Di sini jelas bahwa kasih yang dipraktikkan Yesus adalah kasih yang melampaui kasih manusia yaitu kasih bukan karena tetapi kasih walaupun. Umumnya manusia mengasihi sesamanya karena ada sesuatu yang diharapkannya dari orang tersebut. Selain itu, orang mengasihi sesamanya selalu mempertimbangkan banyak faktor, seperti; melihat status sosial, ekonomi, hubungan persaudaraan, dan karena sebab akibat. Artinya, seseorang mengasihi karena orang lain mengasihinya. Manusia mengasihi sesamanya karena sebelumnya telah menerima suatu perlakuan yang baik atau menguntungkannya, atau karena ada sesuatu yang diharapkan.

Kasih Allah sama sekali berbeda, oleh karena kasih Allah adalah pemberian tanpa kepentingan dan tidak mementingkan diri sendiri, melainkan memberikan diri sendiri (Sanders, 2002, p. 462). Sebaliknya kebanyakan kasih manusia adalah kasih yang mementingkan diri sendiri (Graham, 1978, p. 310). Manusia sangat membutuhkan agape, yaitu kasih yang sempurna, yang tidak berdasar pada kepentingan sendiri dan tidak bergantung pada keadaan yang berubah-ubah. Kasih Allah adalah universal, berlaku untuk seluruh umat manusia, dan merupakan jawaban atas segala masalah manusia dalam keadaan apapun juga. Karena kasih Allah itulah penyataan Kristus hidup dalam diri manusia.

Bagi Paulus, kasih telah dinyatakan sepenuhnya ketika Allah mengutus Anak-Nya dan dalam kematian sang Anak di kayu salib (Rm. 5:6-8). Ini bukanlah sekedar teori atau realitas yang abstrak. Roh Kudus telah mencurahkan kasih itu ke dalam hatinya (Fee, 2004, p. 158). Arti sebenarnya dari kata agape adalah kebajikan yang tak dapat dihalangi. Jika orang Kristen memperlakukan seseorang dengan agape, maka segala tingkah laku dan perbuatan orang tersebut tidak akan menghalangi orang Kristen untuk tetap melakukan yang terbaik baginya Sekalipun orang tersebut menghina atau menyakiti hati, orang Kristen tetap bersikap baik dan mengusahakan yang terbaik baginya (Barclay, 2003, pp. 209-210). Dapat pahami bahwa kasih kristiani bukanlah sesuatu yang bersifat emosional, yang hanya keluar dari perasaan, tetapi juga keluar dari kemauan. Agape adalah kasih ilahi, kasih yang unik. Kasih itulah yang dinyatakan dan dibicarakan di dalam Alkitab. Dan seharusnya hal itu merupakan ciri kehidupan Kristen dan kehidupan gereja (Yoh. 13:35).

Surat 1 Yohanes 4:7-21 mengungkapkan bahwa agape itu mutlak penting bagi Allah, bagi orangorang Kristen, dan bagi kesaksian kepada dunia ini. Agape sudah menyatu dengan pribadi Allah, yakni Allah yang tidak membutuhkan apa-apa tetapi yang memilih untuk 'memberi'. Tabiat Allah adalah kasih. Ia mengasihi, bukan karena Ia mempunyai obyek-obyek yang wajar bagi kasih-Nya, tetapi karena memang tabiat-Nya mengasihi. Kasih-Nya bagi seseorang tidak bergantung pada keadaan-Nya, tetapi bergantung pada hakikat Allah sendiri (Moris, 1982, p. 903). Sebab itu, dikatakan bahwa Allah adalah kasih (1 Yoh. 4:8b). Demonstrasi agape dari Allah yang termulia ada pada salib di mana Ia mengirim Anak-Nya, Kristus Yesus untuk mati bagi dosa-dosa manusia (Graham, 1978, p. 310). Tentang kasih, Piper (2006, p. 21) menuliskan: 
Kematian Kristus tidak hanya menunjukkan kasih Allah (Yoh. 3:16), tetapi juga merupakan pernyataan tertinggi dari Kasih Kristus sendiri bagi semua orang yang menerima kasih-Nya sebagai milik pusaka mereka. Orang Kristen mula-mula, yang paling menderita karena menjadi orang Kristen, menyadari fakta ini: Kristus mengasihi aku dan menyerahkan diri-Nya untuk aku (Gal. 2:20), Kristus telah mengasihi jemaat (gereja) dan telah menyerahkan diri-Nya baginya" (Ef. 2:25), Tidak ada kasih yang lebih besar dari pada kasih seorang yang memberikan nyawa-Nya untuk sahabat-sahabatnya (Yoh. 15: 13), Anak manusia datang bukan untuk dilayani, melainkan untuk melayani dan untuk memberikan nyawa-Nya menjadi tebusan bagi banyak orang (Mat. 20:28).

Boice (1981, p. 14) menjelaskan bahwa kehidupan dan kematian Kritus merupakan penyataan sempurna dari gift-love, yakni pemberian kasih agape (Yoh. 3:16; Rm. 5:8).

Agape adalah kepribadian Allah sendiri yaitu, kasih tanpa syarat dan rela berkorban. Siapapun orangnya, apapun keberadaannya, kasih agape akan mampu menerimanya bahkan mencapainya (Antonius, 2002, p. 124). Jadi, memiliki kasih berarti memiliki kepribadian yang kekal, lebih besar dari harapan atau iman sekalipun. Allah adalah teladan teragung untuk cinta kasih yang tanpa syarat, proaktif dan rela berkorban hingga kepada pengorbanan yang paling mahal.

Kasih berawal pada kasih kepada diri sendiri, lalu kasih kepada sesama dan kasih kepada Allah. Ketiganya tidak terpisahkan, melainkan sebagai satu kesatuan. Orang mampu mengasihi diri sendiri, karena orang tersebut telah menerima kasih dari Allah. Manusia mengasihi karena Allah lebih dahulu mengasihinya (1Yoh. 4:19). Karena dikasihi, lalu mengasihi. Sesudah mengasihi diri sendiri juga seseorang perlu mengasihi sesamanya. Kasih kepada sesamanya merupakan wujud kasih manusia kepada Allah, sumber kasih. Sebab, "Manusia tidak dapat mengasihi Allah yang tidak kelihatan, jika ia tidak mengasihi saudaranya yang kelihatan. Siapa yang mengasihi Allah ia harus mengasihi saudara-saudaranya (1 Yoh.4: 19, 21). Jadi, salah bukti bahwa se- seorang mengasihi Allah adalah mengasihi sesama (bnd. 1Yoh. 4:20). Kasih kepada Allah itu dinyatakan melalui tindakan konkrit kepada sesama. Tuhan Yesus menyatakan bahwa mengasihi sesama merupakan "hukum yang sama" dengan mengasihi Allah (Mat. 22:39). Itu berarti kasih kepada sesama didasarkan atas kasih kepada Allah. Tuhan Yesus memerintahkan para pengikut-Nya agar saling mengasihi sebagaimana Ia mengasihi manusia (Yoh. 13:34). Penekanan Yohanes 13:34 adalah mengasihi sesama sebagaimana Yesus mengasihi manusia.

Sebagai orang Kristen, melakukan perbuatan baik bukan untuk bisa masuk surga, tetapi sebagai bukti menaati dan berbuat apa yang benar untuk mengungkapkan kasih kepada Allah, yang sangat mengasihinya (Wulf,1997, p. 122). Allah memanggil manusia untuk menjawab kasih-Nya dengan mengasihi Tuhan dengan seluruh keberadaan hidup.Dalam Matius 22:37 dikatakan, "Kasihilah Tuhan Allahmu dengan segenap hati, segenap jiwa, dan segenap akal budi. Wiersbe (2012, p. 66) mengatakan, "Dalam Kasih (kemurahan) menunjuk kepada motivasi kehidupan kita. Kita tidak boleh menaati Allah supaya dihargai oleh manusia (Mat. 6:1), tetapi kita menaati-Nya karena kita mengasihi Allah dan umatNya“. Brownlee (1997, pp. 63-64) menuliskan empat alasan manusia hidup dalam kasih. Pertama, kasih berarti pengharapan pada kehidupan manusia sebagaimana Tuhan mengasihi setiap orang (Mat. 5: 45). Kedua, kasih adalah sebuah sikap berbelas kasihan kepada orang yang dinyatakan melalui tindakan kongkrit. Ketiga, kasih merupakan kepekaan kepada kebutuhan dan penderitaan orang lain. Keempat, obyek kasih Kristen tidak terbatas pada orangorang terdekat saja. Rasul Yohanes menegaskan bahwa karena orang-orang Kristen, lahir dari Allah, dan menjadi anak-anak-Nya, maka kasih agape ada dalam dirinya yang baru. Sebab itu, kasih agape itu seharusnya tidak hanya diungkapkan secara lisan melalui perkataan semata-mata, tetapi harus juga dinyatakan melalui perbuatan. Menurut Barclay (2009, p. 155) bahwa makna sesungguhnya dari agape ialah kemurahan hati yang tak dapat ditaklukkan. 
Apabila seseorang memiliki agape, tidak peduli apa pun yang dilakukan atau dikatakan orang lain kecuali yang terbaik bagi mereka, dan ini merupakan corak kasih agape yakni kasih yang mampu mencakup seluruh kepribadian manusia. Jadi, kasih agape adalah penaklukan diri, yang dengannya seseorang menumbuhkan kepedulian terhadap orang lain. Dengan demikian, ciri pertama orang Kristen adalah kepeduliannya terhadap orang lain.

Demikian juga dengan Timotius, rasul Paulus menasihati Timotius agar memiliki kasih agape. Kasih Timotius harus tampak dalam kehidupan dan pelayanannya. Kasihnya terhadap sesamanya itu harus tampak nyata dalam rencana kerja pelayanannya. Kasih Kristus (2 Kor. 5:14) harus menjadi dasar pelayanan penginjilan, dan juga harus tampak dalam kehidupannya. Begitu juga dalam kehidupan seorang guru, dalam melaksanakan tugas sebagai pendidik, kasih Kristus harus menjadi dasar pelayanannya. Kasih guru harus nampak dalam pengajaran dan dalam kehidupannya setiap hari, baik kepada rekan kerja, pimpinan dan juga kepada anak didik. Jadi, kasih yang termulia adalah agape. Jika didasari oleh kasih agape, ketiga kasih lainnya dapat berfungsi dengan baik. Arti dan nilai ketiga kasih itu pun akan bertambah.

Berdasarkan uraian di atas dapat disimpulkan bahwa teladan dalam kasih harus tampak dalam kasih agape, yaitu kasih yang sejati, kasih ilahi, kasih tanpa syarat, kasih yang rela berkorban, kasih yang tidak akan digoyahkan oleh karena situasi dan kondisi yang bangaimana pun buruknya. Ini menunjukkan bahwa kepribadian seorang pendidik dan pengajar yang berketeladanan harus memiliki agape. Dalam agape, seorang pendidik dan pengajar tidak hanya mampu mendoakan musuh-musuhnya, tetapi juga mampu memberkati orang yang membencinya.

\section{Teladan Dalam Kesucian}

Kata benda kesucian dalam 1 Timotius 4:12 diterjemahkan dari kata emag̀nea|(enhagneiai) yang berarti dalam kemurnian atau kesucian. Semua terjemahan bahasa Inggris menggunakan kata purity yang berarti kemurnian sikap yang harus ditunjukkan oleh Timotius di dalam seluruh kehidupannya. Kata ag̀neja| (hagneiai) ini lebih menunjuk kepada kesucian dalam hal moral sebagai salah satu dari lima nilai (virtue) yang disarankan oleh Paulus sebagaimana yang seharusnya dilakukan oleh seorang pengajar atau pemimpin jemaat (Bible Work 7). Barnes (Albert Barnes' Notes) menulis bahwa yang dimaksudkan di sini adalah agar Timotius menjaga dirinya terhadap dosa seks. Sependapat dengan pandangan Barnes di atas, Clarke (Adam Clarke's Commentary) menyatakan bahwa kemurnian di sini mengarah pada kemurnian tubuh dan pikiran. Peringatan ini dimaksudkan agar Timotius menjaga dirinya terhadap godaan wanita yang dapat menjadi godaan besar bagi seorang laki-laki muda. Zehr menjelaskan kata 'kemurnian' sebagai hal yang perlu dijaga oleh seorang pelayan muda, khususnya dalam hal dosa seksual dan cara memperingati seseorang. Zehr (2010, pp. 101-102) mengomentari,

Purity may refer to sexual chastity (IITim 5:2). If so, we see here an implicit correctionof some persons (1Tim 5:11-15; 2Tim 3:6). Purity also means integrity of heart (ITim 5:22). These three interior qualities give authenticity to the young leader's public ministry. Leaders like Timothy who model what they preach and teach are not intimidated by older persons and cultural norms, despite their youthfulness.

Sementara itu, Calvin (2007, p. 74) menuliskan demikian:

Chastity is not merely contrasted with uncleanness, but denotes purity of the whole life. Hence we learn, that they act a foolish and absurd part, who complain that no honor is paid to them, while they have nothing about them that is worthy of applause, but, on the contrary, expose themselves to contempt, both by their ignorance, and by a detestable example of life, or by levity or other abominations. The only way of procuring reverence is, by excellent virtues, to guard ourselves against contempt.

Jadi, sebagai seorang muda, Timotius diingatkan untuk menjaga kemurnian dalam hal percakapan, bahasa, kasih, iman, dan perbuatan. Posisi orang yang menerima Kristus adalah suci, karena Kristus telah 
menyucikan melalui pengorbanan-Nya di kayu salib. Kata 'suci' berarti berorientasi pada Yang Suci. Dalam Kamus Besar Bahasa Indonesia (2002, p. 1096), "Suci berarti bersih, bebas dari dosa, keramat dan murni. Sedang 'kesucian' berarti kebersihan hati, kemurnian." Dalam bahasa Inggris ada tiga kata yang digunakan untuk kata suci yakni: Pertama, holy yaitu, suci. Kedua, whole yaitu sehat. Ketiga, holistic yaitu utuh. Ketiga kata ini memiliki akar yang sama serta mempunyai makna yang saling berkaitan dan melengkapi. Kesucian berarti pangkal kesehatan yang menjamin keutuhan sebuah organisme atau sistem (Sinamo, 2010, pp. 73-74). Blaiklok (1981, p. 45) mengatakan bahwa, "Kesucian menyangkut kemurniaan hati dan hal memerintah diri sendiri." Jadi, kesucian adalah prasyarat utama untuk hidup sehat, baik secara jasmani terlebih secara rohani. Dapat dipahami bahwa hidup suci adalah hidup yang telah diperbaharui, dibenarkan, diselamatkan, dan dipisahkan dari kehidupan yang berdosa. Menurut Tu'u (2010, p. 46), orang-orang yang telah percaya Yesus Kristus dengan sungguh-sungguh, yakin jika dosanya telah dihapuskan dan dibersihkan oleh Tuhan.

Panggilan hidup kudus menuntut manusia untuk berdisiplin dengan mempunyai sikap yang pantang mundur (Roberts, 1988, p. 32). Pikiran-pikiran yang suci dan murni perlu dikembangkan dalam sikap dan perilakunya. Menurut Tu'u (2010, p. 46) "Hidup suci dan murni perlu dikembangkan dan diperjuangkan karena Tuhan yang telah membebaskan dan menyelamatkan adalah suci dan kudus. Dalam hubungannya dengan kesucian, maka Paulus menasihati Timotius soal standar moral hamba Tuhan. Paulus tahu bahwa Timotius masih muda sehingga mudah terpengaruh oleh dosa. Firman Tuhan mengajar agar setiap orang mampu untuk menjadi teladan dalam kesucian. Kesucian berarti kesetiaan kepada standar Kristus, kesetiaan yang tak dapat ditaklukkan (Barclay, 2008, p. 155). Itu berarti, kesucian perlu ditunjukkan dengan pengendalian diri terhadap godaan dosa. Seorang Kristen harus mempunyai standar kehormatan dan ketulusan hati, pengendalian diri dan kesucian, disiplin dan tanggung jawab yang lebih tinggi daripada standar dunia (Barclay, 2008, p. 155). Warren (1996, p. 67) mengatakan,

Kesucian sangat penting karena kita hidup di dalam dunia yang jahat sekarang ini. Efesus sebuah kota yang menjadi pusat penyimpangan seksual, dan orang muda seperti Timotius diperhadapkan kepada banyak godaan. Ia harus mempunyai hubungan yang murni dengan perempuan-perempuan di dalam jemaatnya (ITim 5:2) dan memelihara agar pikiran, hati, dan tubuhnya tetap suci.

Paulus menasihati Timotius agar memiliki iman yang teguh, kasih yang semakin besar dan terutama supaya ia menjadi teladan dalam kesucian hidup. Dengan demikian, tidak ada seorang pun yang menganggap ia rendah hanya karena umurnya yang masih muda. Tetapi ia dapat menjadi panutan dan model yang baik, yang patut diikuti dan diteladani oleh orang-orang yang dipimpinnya.

Dari uraian di atas nampak bahwa setiap orang dituntut untuk menjaga kesucian hidup dengan cara menjaga hati dan pikiran, serta tidak menodai dirinya dengan hal-hal buruk, kotor dan najis. Kesucian hidup perlu ditunjukkan melalui pengendalian diri terhadap dosa. Pengendalian diri atau penguasaan diri adalah terjemahan dari bahasa Yunani engkrateia (Strong, 1890, p. 25). Senada dengan apa yang disampaikan oleh Graham (1978, p. 310) mengatakan, penguasaan diri berasal dari kata Yunani engkrateia yang berarti kuat, telah menguasai, dapat mengontrol pikiran dan sikap pribadi. Kata ini juga dipakai untuk seorang atlit yang mendisiplin tubuhnya (1 Kor. 9:25) dan untuk usaha orang kristiani dalam menguasai kebutuhan seks (1 Kor. 7:9). Kata engkrateia berasal dari kata bahasa Yunani kratos, "kekuatan" (Vine, 1940, p. 114); bahasa Yunani yang diterjemahkan kuasa. Menurut Aristoteles (1999, p. 104), "Pengedalian diri merupakan salah satu kebajikan. Kebajikan tersebut merupakan dasar kepribadian sekaligus menjadi wujud nyata dari kebijaksanaan praktis." Pengendalian diri dalam terjemahan King James Version (KJV) berarti kesederhanaan dan penguasaan diri. Kata yang dipakai oleh dalam KJV adalah temperance yang berarti mengua- 
sai keinginan diri dan nafsu/hasrat diri. Sedang menurut Sidjabat (2011, p. 256) pengendalian diri merupakan ketenangan dan pengendalian atas dorongan-dorongan yang timbul dalam hati dan pikiran agar dapat mencapai hidup yang lebih baik. Allah mengehendaki supaya manusia mengendalikan dirinya dalam hawa nafsu (Ams. 23:1-3), perkataan (Ams. 25:1-2), pengendalian lidah (Yak. 3:5-10) Sidjabat (2011, p. 256). Selain itu Unarto (2006, pp. 129-138) juga menambahkan pengendalian diri dengan menguasai mata (Mat. 6:22-23), menguasai perasaan (Flp. 2:5) sehingga dapat mengendalikan amarah, iri hati, ketidaksabaran, serta menguasai pikiran (Flp. 4:8) sehingga terhindar dari pikiran yang jahat, pikiran yang kotor dan pikiran yang serakah. Sidjabat (2011, pp. 257-258) memaparkan cara agar bertumbuh dalam pengendalian diri sebagai berikut:

Ada sejumlah prinsip yang dapat membantu pertama, teruslah memandang diri telah tersalib bersama Yesus dalam kedagingan.Pandanglah diri senantiasa telah menjadi satu dengan Yesus Kristus dalam penyaliban-Nya, kematian dan kebangkitan-Nya. Kedua, berilah diri supaya selalu hidup oleh Roh Allah dan dipimpin olehNya Menurut Paulus, Allah menghendaki umatNya agar dipenuhi oleh Roh Kudus (Ef. 5:18). Hal ini perlu dilakukan karena pengendalian diri pada dasarnya merupakan buah Roh itu sendiri (Gal. 5:22-23). Ketiga, mintalah kepada Tuhan agar Dia mengarunikan sifat penguasaan atau pengendalian diri dengan pengucapan syukur. Keempat, nyatakanlah bahwa Allah memberikan kepada kita bukan roh yang membangkitkan kelemahan, melainkan kekuatan, kasih dan pengendalian diri (2Tim. 2:17). Kelima, serahkanlah anggota tubuh, juga pikiran dan emosi dan suara hati kepada Tuhan sebagai persembahan yang kudus kepada-Nya. Keenam, bangunlah persahabatan dengan kelompok teman seiman untuk menumbuhkan iman dan kepribadian secara bersama-sama.

Zoschak (1995, pp. 199-212) menjelaskan bahwa ada empat fungsi dari pengendalian atau penguasaan diri yakni pertama, membantu orang-orang beriman mengalahkan roh penyembahan berhala sehingga mampu membatasi diri dalam tindakan, pemikiran dan perasaan termasuk terhadap hal-hal yang Tuhan sediakan. Kedua, melawan roh percabulan. Orang beriman yang mengasihi dunia akan terjerumus dalam dosa keinginan daging, keinginan mata, keangkuhan hidup yang melawan kehendak Tuhan. Keti$g a$, membantu orang-orang beriman untuk tidak mencobai Kristus. Keempat, membantu orang-orang beriman agar tidak bersungut-sungut.

Rasul Paulus menasihati Timotius agar menjadi teladan dalam kesucian melalui pengendalian diri, yakni mampu mengawasi dirinya sendiri. Dalam ayat 16b dikatakan, "Awasilah dirimu sendiri". Kata 'awas' berarti suatu peringatan agar seseorang berhati-hati. Drewes, Haubeck, dan von Siebenthal (2006, p. 219) mengatakan, epece (epekhe) kata imperatif datif dari kata eqeç, (epekheō) yang berarti berpegang pada, mengawasi." Menurut Newman, (1995, p. 63) "Kata eqecw, (epekhō) dari aorist kata epescon (epeskhon) intrans yang berarti menatap, menaruh perhatian; e/Cromon (ev. cronon) tinggal beberapa lama (Kis. 19:22; trans berarti berpegang kepada (Flp.2:16)." Dengan demikian epece(epekhe) berarti berpeganglah kamu pada. Alkitab TB menggunakan frase awasilah.

Kata yang digunakan untuk 'dirimu' adalah seautw/ (seautoi, pronoun reflesif datif maskulin tunggal) dari kata seautou (seautoū) yang berarti yourself atau dirimu sendiri (Bible Works 7). Menurut Newman, (1995, pp. 152), "Kata seautou" (seautō̄) berarti refleksif dirimu sendiri". Dengan demikian, frase 'awasilah dirimu sendiri' dapat pula diterjemahkan sebagai 'lihatlah dan berilah perhatian kepada dirimu sendiri, jagalah dirimu sendiri, kontrollah dirimu sendiri dan berpeganglah pada dirimu sendiri'.

Kata 'awasilah dirimu' dalam I Timotius 4:16 , mengandung maksud 'berikan dirimu sepenuhnya kepadanya". Timotius harus berusaha menjaga kehidupannya, dengan sungguh-sungguh, supaya kehidupan dan pelayanannya dapat menjadi berkat bagi orang lain (Wiersbe, 2012, p. 71). Dalam ayat itu, Paulus menempatkan ungkapan 'dirimu sendiri' lebih dahulu daripada 'ajaranmu'. Kata "dirimu sendiri" (Yunani: heauton) yang berarti penegasan. Rasul Paulus menegaskan bahwa Timotius perlu mem- 
perhatikan dirinya sendiri, bukan hanya memperhatikan diri orang lain. Paulus memberikan peringatan yang sama juga kepada para penatua di Efesus dalam pesan perpisahannya, 'Jagalah dirimu' (Kis. 20: 28). Itu berarti mengawasi diri merupakan sesuatu yang sangat urgen, mengingat sekarang ini banyak hamba Tuhan yang telah meninggalkan pelayanan karena kehidupan mereka tidak sesuai dengan pekerjaan sebagai hamba Tuhan. Seorang pendidik dapat saja terlalu sibuk menolong orang lain sehingga ia melalaikan dirinya dan kehidupan rohaninya sendiri. Itu sebabnya sehingga seorang pendidik perlu mengawasi dirinya sendiri sebelum mengawasi orang lain. Dalam Alkitab ada nasihat agar setiap orang mengawasi diri sendiri terlebih dahulu, bukan orang lain. Nasihat Paulus ini relevan mengingat kebanyakan orang lebih suka mengawasi orang lain daripada mengawasi diri sendiri (Unarto, 2006, p. 123). Dalam konteks itulah rasul Paulus mengingatkan, "Baiklah tiap-tiap orang menguji pekerjaannya sendiri; maka ia boleh bermegah melihat keadaannya sendiri dan bukan melihat keadaan orang lain" (Gal. 6:4). Penguasaan diri adalah kemampuan menguasai diri dengan pertolongan kuasa Roh Kudus. Artinya, Roh Kudus yang tinggal di dalam diri manusia akan memampukan manusia untuk mengendalikan diri. Namun bagaimanapun juga, penguasaan diri menuntut usaha dari manusia untuk mengikuti pimpinan Roh Kudus. Dalam konteks pendidikan, ada dua sisi yang merupakan syarat penentu keberhasilan seorang pendidik (Sopater, Octavianus, Pardede, 1994, pp. 1314) yakni: Pertama, kepribadian. Kehidupan pribadi seorang pendidik sangat menentukan gerak-gerik pelayanan dan penanganan tugas-tugasnya. Seorang pendidik yang gagal secara pribadi dalam berumah tangga atau dalam kehidupan pribadi lainnya, maka hal itu sangat berpengaruh atas seluruh tugas dan pelayanannya. Dalam mengajar, kepribadian seorang pendidik jauh lebih disoroti dan diselidiki dibandingkan dengan orang-orang.lain. Jatuh bangunnya seorang pendidik sangat bergantung kepada kehidupan pribadinya. Seorang pendidik haruslah berkepribadian terbuka dan tidak kaku, bersedia menerima pendapat orang lain dan mudah mengaku salah jika memang bersalah serta mengampuni sesama. Kedua, kerohanian. Selain kepribadian, kerohanian merupakan prinsip utama dalam pendidikan. Kekuatan pendidik tidak diukur dari yang dapat dikerjakan, tetapi diukur dari hubungannya dengan Tuhan. (Sopater, Octavianus, Pardede, 1994, p. 16). Jadi seorang pendidik haruslah berpikir secara alkitabiah, karena pengajarannya bersumber pada apa yang dikatakan Alkitab; konsep pengajarannya adalah konsep Alkitabiah.

Penekanan pada kata "dirimu sendiri" menegaskan bahwa pendidik sendiri perlu memiliki doktrin yang benar. Dalam mengajar, pendidik harus terus bertekun dalam melaksanakan tugas yang telah dipercayakan kepadanya. Istilah bertekun termasuk istilah inti yang dipakai untuk melukiskan ketabahan seorang Kristen (Gal. 3:10; Ibr. 8:9; Yak. 1:25; Kis. 14:22; Kol. 1:23). Jadi pada dasarnya yang dimaksudkan adalah sama dengan "tinggallah" dari Yohanes 15 dan 1 Yohanes. Ini berarti, orang yang mengawasi diri adalah orang yang tetap tinggal di dalam Kristus dan setia melakukan apa yang Kristus perintahkan. Dalam kaitan dengan pengajaran, maka mengawasi diri berarti segala sesuatu yang bersifat pribadi yang menjadi syarat dalam pengajaran. Sehubungan dengan mengawasi diri, Barnes (Albert Barnes' Notes) memberi komentar berikut:

This may be understood as relating to everything of a personal nature that would qualify him for his work. It may be applied to personal piety; to health; to manners; to habits of living; to temper; to the ruling purposes; to the contact with others. In relation to personal religion, a minister should take heed:(1) That he has true piety; and, (2) That he is advancing in the knowledge and love of God. In relation to morals, he should be upright; to his contact with others, and his personal habits, he should be correct, consistent, and gentlemanly, so as to give needless offence to none. The person of a minister should be neat and cleanly; his manners such as will show the fair influence of religion on his temper and deportment; his style of conversation such as will be an example to the old and the young, and such as will not offend against the proper laws of courtesy and 
urbanity. There is no religion in a filthy person; in uncouth manners; in an inconvenient and strange form of apparel; in bad grammar, and in slovenly habits - and to be a real gentleman should be as much a matter of conscience with a minister of the gospel as to be a real Christian. Indeed, under the full and fair influence of the gospel, the one always implies the other. Religion refinaaes the manners - it does not corrupt them; it makes one courteous, polite, and kind - it never produces boorish manners, or habits that give offence to the well-bred and the refined.

Menurut Barnes mengawasi diri berarti dalam hubungan dengan orang lain, seorang pendidik harus memiliki tata krama, sikap hidup benar, tidak pemarah, dan memiliki kesalehan hidup. Dalam hubungan dengan agama, ia harus memiliki kesalehan sejati dan maju dalam pengetahuan dan kasih Allah. Dalam hubungan dengan moral, ia harus tegas dalam berhubungan dengan orang lain dan kebiasaan pribadinya harus rapi, bersih, benar, konsisten, sopan, dan mampu menunjukkan sikap yang adil terhadap agama, sehingga tidak menyebabkan adanya pelanggaran. Jadi, seorang pendidik harus mampu menjadi teladan dalam perkataan. Perilakunya tidak boleh bertentangan dengan hukum dan sopan santun yang berlaku. Senada dengan itu, Gill's (John Gill's Exposition of the Entire Bible) juga berkomentar sebagai berikut,

Not as a man, or a Christian only, but as a minister; and as every minister should take heed to his life and conversation, that it be exemplary, as in 1Ti.4:12 to his gifts, that they be not lost, or neglected, but used and improved; to the errors and heresies abroad, that he be not infected with them; and to his flock, which is the other part of himself, that he feed it with knowledge and understanding: and to thy doctrine: preached by him, that it be according to the Scriptures, be the doctrine of Christ, and his apostles, and according to godliness; that it tend to edification, and is pure, incorrupt, and all of a piece; and that it be expressed in the best manner, with all boldness and plainness; and that he defend it against all opposition.

Gill's menekankan makna mengawasi diri terkait dengan kehidupan yang harus menjadi contoh dalam percakapan, konsisten dalam hidup sesuai dengan firman Tuhan, dan hidup dalam keserupaan dengan Kristus. Pendidik harus hidup suci termasuk tidak terlibat dalam korupsi. Jadi, orang yang mengawasi diri adalah orang yang memiliki pribadi yang berintegritas dalam hidupnya, dan seharusnyalah hal itu yang menjadi ciri khas kehidupan seorang pemimpin rohani (Bangun, 2010, p. 102). Sehubungan dengan mengawasi diri, Henry (Matthew Henry's Commentary) juga berkomentar sebagai berikut,

He presses it upon him to be very cautious: "Take heed to thyself and to the doctrine, consider what thou preachest; continue in them, in the truths that thou hast received; and this will be the way to save thyself, and those that hear thee." Observe, (1.) Ministers are engaged in saving work, which makes it a good work. (2.) The care of ministers should be in the first place to save themselves: "Save thyself in the first place, so shalt thou be instrumental to save those that hear thee." (3.) Ministers in preaching should aim at the salvation of those that hear them, next to the salvation of their own souls. (4.) The best way to answer both these ends is to take heed to ourselves, etc.

Menurut Henry, mengawasi diri berarti hidup di dalam kebenaran yang telah diterima; harus membuat pekerjaannya menjadi baik; pengajarannya harus bertujuan untuk menyelamatkan dirinya; dan juga orang yang mendengarnya, bahkan harus menjaga dirinya agar menjadi alat untuk dapat menyelamatkan orang lain. Jadi penekanan utama Henry di sini adalah seorang pelayan harus terlibat dalam pekerjaan penyelamatan, dan cara terbaik untuk tujuan penyelamatan ini adalah memperhatikan diri.

Timotius diminta untuk mengawasi diri sendiri, bukan hanya sebagai orang Kristen, tetapi juga sebagai seorang pelayan yang mampu menjadi teladan. Ia harus mengawasi diri supaya karunia yang ada padanya tidak hilang. Ia juga tidak boleh terpengaruh oleh ajaran sesat. Maksud Paulus meminta Timotius untuk mengawasi diri yaitu supaya kemajuan Timotius dapat dilihat oleh semua orang. Untuk mencapai kemajuan itu maka diperlukan ketekunan dalam segala hal. Itu berarti, seorang pendidik harus menjaga dirinya supaya ia juga maju dalam pekerja- 
an Tuhan. Ia harus senantiasa berjalan bersama Tuhan dalam terang firman-Nya, sehingga ia tidak akan sesat dari firman Tuhan dan kehidupannya yang suci akan nyata kepada semua orang. Pemberitaan Injil yang dilakukan oleh seseorang tidak akan berhasil jikalau tidak disertai dengan kehidupan yang suci, yakni kehidupan yang menjadi teladan bagi semua orang. Dengan demikian, ia dapat menyelamatkan dirinya sendiri dan juga orang-orang yang mendengarnya.

Dapat dikatakan bahwa mengawasi diri berarti setiap orang percaya atau pendidik harus terlibat dalam pekerjaan penyelamatan. Maksudnya jika pendidik mengawasi diri maka dia dapat menyelamatkan dirinya sendiri dan juga menyelamatkan orang yang mendengar ajarannya. Mengawasi diri tidak hanya ketika seseorang berhubungan dengan orangorang yang seiman, melainkan kepada siapa pun saja. Alasannya karena penguasaan diri bukan hanya ketika berada di antara orang banyak yang mengenal, melainkan juga ketika berada di tengah-tengah orang yang tidak mengenalnya (Unarto, 2006, p. 123). Paulus meminta kepada Timotius agar menjaga kemurnian dirinya.Kemurnian diri hanya dapat diperoleh bila hati dan pikiran seseorang telah bersih dan suci. Dengan demikian, Roh Allah sendiri yang akan masuk mengisi hati dan pikirannya untuk terus hidup dalam kemurnian diri. Dapat dikatakan bahwa agar seseorang mampu mengawasi dirinya maka dia harus menyerahkan hidupnya sepenuhnya untuk dipimpin oleh Roh Kudus, karena Roh Kuduslah yang mengawasi segala keinginan, kegemaran dan kesenangan. Sama seperti atlit yang mendisiplin dirinya dengan memelihara tubuh dan terus berlatih sehingga berhasil dalam perlombaan. Berdasarkan uraian di atas jelas bahwa menjadi teladan dalam kesucian berarti menjaga kemurnian tubuh dan pikiran, karena kesucian menyangkut kemurnian hati dan hal memerintah diri sendiri. Sebab itu, setiap orang perlu mengawasi dirinya terlebih dahulu sebelum mengawasi orang lain, dan untuk dapat mengawasi diri, maka setiap orang perlu menyerahkan dirinya dipimpin oleh Roh Kudus.
Berdasarkan penjelasan di atas tentang kepribadian guru agama Kristen maka dapat disimpulkan bahwa kepribadian yang baik sangat dibutuhkan dari setiap orang. Sebab itu, setiap orang harus berusaha memiliki kepribadian yang baik serta mampu menjadi teladan dalam kehidupannya serta tampak dalam perkataan, tingkah laku, kasih, kesetiaan, dan kesucian. Demikian juga bagi seorang guru Kristen, mereka dituntut untuk mampu menjadi teladan dalam kehidupan khususnya dalam pengajarannya. Sebab, pengajaran yang berhasil tidak hanya disampaikan lewat perkataan saja, tetapi juga harus disertai dengan perbuatan. Keberhasilan pengajaran tidak dapat dipisahkan dari keteladanan seorang guru.

\section{KESIMPULAN}

Salah satu indikator penting dalam analisis kepribadian guru agama Kristen dalam perspektif 1 Timotius 4:11-16, adalah "Keteladanan." Dalam kajian ini Timotius diharapkan meninggalkan sesuatu yang berkesan pada orang lain. Selain itu, Timotius diminta oleh Paulus agar menjadi pengajar atau guru yang memiliki kepribadian kepada jemaat sekalipun dirinya masih muda.Kualifikasi kepribadian seorang pengajar yang harus dimiliki oleh Timotius harus tampak dalam keteladanannya. Keteladanan merupakan hasil dari tindakan proses ketaatan dan ketekunan akan firman Tuhan. Oleh karena itu, keteladanan merupakan sikap yang harus dituntut dari setip manusia. Keteladanan harus bersifat permanen dan saling berkaitan dengan kedewasaan rohani. Orang dewasa rohani adalah orang yang mempunyai integritas dan selalu berusaha untuk berbuah rohani, sehingga Paulus mendorong agar Timotius menjadi teladan dalam hidup dan pelayanannya. Pelayanan yang dilakukan tidak hanya dengan kata-kata saja, tetapi yang terpenting yaitu harus disertai dengan sikap dan tindakan yang dapat menjadi panutan bagi seluruh jemaat. Dengan demikian, guru agama Kristen di zaman era digital ini dituntut untuk memberikan teladan tentang apa yang diajarkan, yang diwujudkan di dalam kehidupan sehari-hari. Dengan menjadi teladan, dirinya akan dihormati oleh peserta didik di sekolah. 


\section{DAFTAR RUJUKAN}

Abineno, J.L.Ch. 1989. Tafsiran Alkitab: Surat Efesus. Jakarta: BPK Gunung Mulia.

Antonius, Tanan \& Ciputra. 2002. Menjadi Manusia Unggul yang Disertai Tuhan, Jakarta: Bethlehem.

Aristoteles.1999. Nichomachean Ethics, terj. W.D. Ross. ttp: Batoche Books.

Bagus, L. 1996.Kamus Filsafat. Jakarta: Gramedia.

Bahan Elektronik, Bible Work 7

Bangun, Y. 2010. Integritas Pemimpin Pastoral: Menjadi Pemimpin Yang Memadukan Kata Perbuatan, Iman Ilmu, Teori Praktik, Jabatan Integritas. Yogyakarta: Andi.

Barclay, W. 2003.Pemahaman Alkitab Setiap Hari: Surat-Surat Galatia dan Efesus, terj. W. Wahono. Jakarta: BPK Gunung Mulia.

Budiman, Rudy. 2008. Tafsiran Alkitab Surat-Surat Pastoral I \& II Timotius dan Titus. Jakarta: BPK Gunung Mulia.

Barclay, William. 2008. Pemahaman Alkitab Setiap Hari Injil Matius Ps. 1-10. Jakarta: BPK. Gunung Mulia.

Barclay, W. 2009. Pemahaman Alkitab Setiap hari: Surat 1 dan 2 Timotius, Titus, Filemon. Jakarta: BPK Gunung Mulia.

Barnes', A. Albert Barnes' Notes on the Bible, Bahan Elektronik e-Sword.

Boice, J.M. 1981. The Espistles of John. Grand Rapids, Mich: Zondervan Publishing House.

Brownlee, M.1997. Tugas Manusia dalam Dunia Milik Tuhan.Jakarta: Gunung Mulia.

Calvin, J. 2007. The Oxford Bible Commentary. Oxford New York: University Press.

Clarke, A. Adam Clarke Commentary of the Bible, Bahan Elektronik $e$-Sword.

Doni, Koesoema A. 2010. Pendidikan Kepribadian: Strategi Mendidik Anak di Zaman Global. Jakarta: Grasindo.

Douglas, J.D. 1995.Ensiklopedi Alkitab Masa Kini Jilid II M-Z. Jakarta: Yayasan Komunikasi Bina Kasih/OMF.
Drewes, B.F., Haubeck, W. dan von Siebenthal, H. 2006. Kunci Bahasa Yunani Perjanjian Baru. Jakarta: BPK Gunung Mulia.

Fee, G.D.P. 2004. Roh Kudus dan Umat Allah. Malang: Gandum Mas.

Gultom, Andar. 2007. Profesionalie, Standar Kompetensi, dan Pengembangan Profesi Guru $P A K$. Bandung: Bina Media Informasi.

Graham, B. 1978.Roh Kudus: Kuasa Allah Dalam Hidup Anda. Bandung: Lembaga Literatur Baptis.

Haak, C.J. 1996. Bahan Ajar I Timotius: Pedoman Kehidupan Gerejani. Jakarta: STM GGR.

Henry, M. Matthew Henry's Commentary on the Whole Bible, Bahan Elektronike-Sword.

Hornby A.S. dan Parnwell, E.C. 1972. Leaner's Dictionary. Kualalumpur: Oxford University Press.

Kee, H.C. 1991. The New Testament Speaks. Michigan: Abingdon Press.

Kunandar. 2007. Guru Profesional: Implementasi Kurikulum Tingkat Satuan Pendidikan (KTSP) dan Persiapan Menghadapi Sertifikasi Guru. Jakarta: Raja Grafindo Persada.

Kertajaya, H, 2010. Grow with Character: The Model Marketing, Jakarta: Gramedia Pustaka Umum.

Koesoema A., Doni. 2010. Pendidikan Kepribadian: Strategi Mendidik Anak di Zaman Global. Jakarta: Grasindo.

Lebar, Lois E. Educational That Is Christian: Proses Belajar Mengajar Kristiani \& Kurikulum Yang Alkitabiah. Malang: Gandum Mas.

Morris, L. 1982. I Yohanes dalam Tafsiran Alkitab Masa Kini, Jilid 3. Jakarta: BPK Gunung Mulia.

Mark, Rutland. 2009. Kepribadian Itu Penting, Terj. Ly Yen, Jakarta: Light Publishing.

Nahampu, Damayanti. 2017. "Kompetensi Kepribadian Guru Dalam Pelaksanaan Pembelajaran Anak Autis Di SLB C Karya Bhakti Purworejo." Jurnal Widia Ortodidaktika, 6 (5). 
Nainggolan, John M. 2006. Menjadi Guru Agama Kristen: Suatu Upaya Peningkatan Mutu Dan Kualitas Profesi Keguruan, (Bandung: Generasi Info Media.

Nainggolan, J.M. 2008. Strategi Pembinaan Warga Gereja, Bandung: Generasi Info Media.

Newman. Barclay M. 1995. Greek: English Dictionary of the New Testament (Bible Students), Amer Bible Society: Teachers Guide edition.

Offner, H. 1994. Buah Roh. Jakarta: Perkantas.

Piper, J. 2006.The Passion of The Christ. Surabaya: Momentum, 2006.

Roberts. 1988. Hidup Suci: Panggilan Bagi Setiap Orang Kristen. Bandung: Lembaga Literatur Baptis.

Rutland, M. 2009. Kepribadian Itu Penting, Terj. Ly Yen. Jakarta: Light Publishing.

Said. 2010. Pendidikan Kepribadian di Sekolah. Surabaya: Jepe Press Media Utama.

Sanders, J. O. 2002. Kemuridan Rohani. Batam Centre: Gospel Press.

Sidjabat, B.S. 2011. Membangun Pribadi Unggul: Suatu Pendekatan Teologis Terhadap Pendidikan Kepribadian. Yogyakarta: PBMR Andi.

Sidjabat, B.S. 1999. Strategi Pendidikan Kristen Suatu Tinjauan Teologis-Filosofis. Yogyakarta: Andi

Sinamo, J. 2010. 8 Etos Keguruan. Jakarta: Darma Mahardika.

Sopater, S., Octavianus, P., \& Pardede, P. 1994. Sebuah Bunga Rampai Pertumbuhan Gereja. Yogyakarta: Andi.

Strong, J. 1890. Strong's Exhaustive Concordance of the Bible. Nashville: Abington.

Sugioyono. 2014. Metode Penelitian Manajemen. Bandung: Alfa Beta.
Sari, Hasmila, Shabri, 2016. "Hubungan Tipe Kepribadian Dengan Motivasi Belajar Pada Mahasiswa Kurikulum Berbasis Kompetensi Fakultas Keperawatan Universitas Syiah Kuala." Idea Nursing Journal, VII (2).

Tanan, Antonius \& Ciputra, 2002.Menjadi Manusia Unggul yang Disertai Tuhan. Jakarta: Bethlehem.

Tong, Stephen. 2008. Arsitek Jiwa II. Surabaya: Momentum.

Tim Penyusun. 2002. Kamus Besar Bahasa Indonesia. Jakarta: Balai Pustaka.

Tu'u, Tulus. 2010. Pemimpin Kristen Yang Berhasil Jilid 2. Bandung: Bina Media Informasi.

Uan, Moh. User, 2001.Menjadi Guru Profesional. Bandung: Remaja Rosdakarya.

Unarto, E. 2006. Bertumbuh Dalam Kepribadian Baru: Seri Pelajaran Alkitab Praktis Untuk Pribadi, Keluarga dan Kelompok Sel. Jakarta: Pustaka Sorgawi.

Vine, W.E. 1940. Expository of New Testament Words. Old Tappan: Revell.

Wulf, D. 1997. Kenalilah Diri Anda. Malang: Gandum Mas.

Wiersbe, W.W. 2012. Loyal di dalam Kristus Mengikut Raja Segala Raja Bandung: Kalam Hidup.

Wiersbe, W.W. 1996. Setia Di Dalam Kristus, Bandung: Kalam Hidup.

Tung, Khoe Yao. 2016. Terpanggil Menjadi Pendidik Kristen Yang Berhati Gembala. Yogyakarta: Andi Offset.

Zehr, P.M. 2010. I \& 2 Timothy Titus. Scottdale, Pennsylvania: Herald Press.

Zoschak, G. 1995. Membangun Kepribadian Anda. Jakarta: Immanuel. 